\title{
Research on intensive utilization of land and settlements protection under rural housing reconstruction in Chengdu Plain
}

\author{
B. Shu ${ }^{1}$, T.-N. Gao ${ }^{1} \&$ Y.-X. Zhao ${ }^{2}$ \\ ${ }^{1}$ School of Architecture, Southwest Jiaotong University, China \\ ${ }^{2}$ Sichuan Southwest GuaXia Architectural Design Institute \\ Corp. Ltd., China
}

\begin{abstract}
Land consolidation and settlement protection is a very important part of urban and rural integration development. The way of analyzing the causes of the Chengdu Plain traditional settlement genesis, forms, and positive aspects, as well as negative impacts on the settlements in the process of land consolidation; the important issues under rural housing reconstruction and what has to be considered in new rural design in the future, are summed up. These strategies do benefit on raising land utilization level in rural residents and avoiding the destruction of the traditional settlement. Furthermore, these experiences help people to plan and design the new rural construction on the premise of protecting traditional culture so as to achieve a win-win situation of land use and construction of a new rural area.
\end{abstract}

Keywords: Lin Pan, settlement pattern, intensive utilization, rural houses, tradition.

\section{Introduction}

Urban and rural development means to consider the city and the countryside, agriculture and industry, farmers and citizens as a whole, and solve related issues into the plan for social and economic development integrally. The economic and intensive use of land is significant to improve the efficiency of land resources utilization, alleviate the contradiction between supply and demand of urban and rural land and promote the long-term development of the national economy. Meanwhile, it provides reasonable theoretical proof for the reconstruction project 
of rural houses in an earthquake stricken area. Chengdu plain is a demonstration of rural and urban development. In the process of implementing the "three concentrations", the supply of land resources becomes the core issue of rural and urban development. Therefore, promoting the intensive utilization of rural construction land has profound meaning in dealing with this issue. Especially in post-disaster reconstruction work, only by adopting effective planning and strategies, is the intensive economy capability improved. Therefore, a good living environment and perfect infrastructure can be successively created. Based on this, the traditional settlement in Chengdu Plain should be emphasized and protected; its pattern should be regarded as a critical principle of crackage reconstruction and new rural construction, so as to guarantee the simultaneous formation and harmonious development of the social economy and traditional characteristics when making highly-effective use of the land. By improving the level of economical use of land-intensive and strengthening the living protection of traditional settlements, accumulating the design, management, engineering experience, then summarizing planning and design strategies for crackage reconstruction, to people can provide reasons for decision-making and practical guidance in the process of new rural construction.

\section{The formation of a traditional settlement in Chengdu plain}

Land readjustment will inevitably lead to intensive utilization of land. Farmers can get economic compensation through the principle of land replacement, so they agree to transfer their land use rights. In addition, at the same time, the rural residential pattern also changes from the original relatively scattered village layout into a concentrated placement. This shift has great influence on the settlement form in Chengdu plain. Lin Pan, which is full of characteristics, surrounded by tall bamboo and green water will cease to exist. The earth landscape will change greatly, too. As one of the highly developed regions of farming civilization in our country, rich and beautiful Chengdu plain has been described in the pre-Qin ancient books named Legends of Mountains and Seas.

Settlement is the place where people live in compact communities. The settlement layout form in our country mainly has two characteristics: the centralized model in northern regions and decentralized model in southern regions. The most representative settlement form in Chengdu plain is the "LinPan" layout - villages dispersed into individual settlements, clear and running water in front of separated families, houses are surrounded by forests and plants, thatched cottages are nestled in the bamboo forest. Just as poet Fan Cheng-da said, that West Sichuan is a place: everywhere canals and bamboo surround the homesteads. This type of homestead is called "LinPan" [1]. The village consisting of LinPan is a typical decentralized model of village structure, also an important part of the Chengdu plain ecological system, which is a comprehensive product of a long-term ecological process and non ecological process and constitutes a stable ecological system with farmland, drainage and so on. Meanwhile, LinPan is an important carrier of history and regional culture $[2,3]$. 


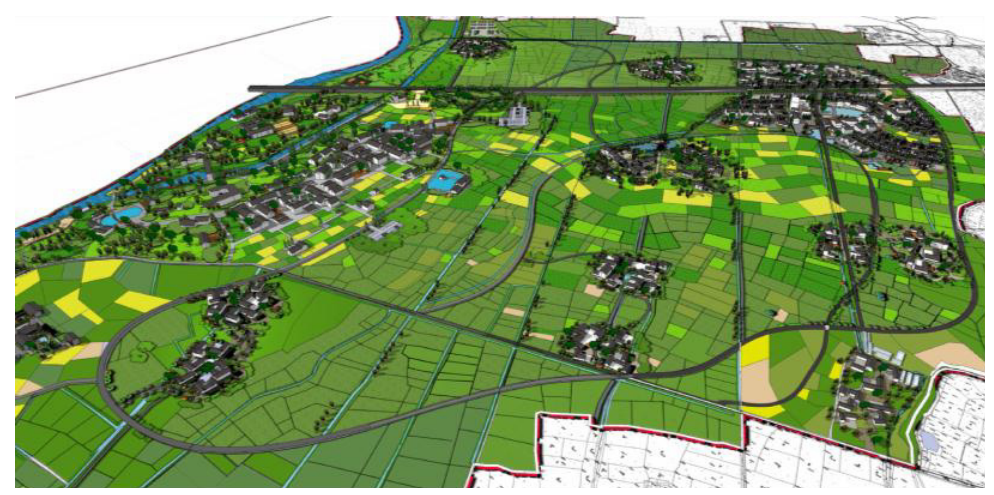

Figure 1: $\quad$ Typical settlement in Chengdu plain.

\subsection{Formation reasons}

The traditional settlement seems to form naturally. In fact it is the results of people's selection in specific natural conditions, and adapted to the specific climate, mode of production and life style [4]. The formation of a Chengdu plain traditional settlement form mainly has the following key factors:

\subsubsection{Physioclimate feature}

The climate of Chengdu plain is moist and it is burning hot in summer. Because it is located at the bottom of Sichuan basin, the wind is very light and wind speed is $2.0 \mathrm{~m} / \mathrm{s}$ below. Such a climate requires that houses should be adequately ventilated as the humidity is so intense. And there are a lot of tall bamboos around the house. They cannot only be used as building material, but also provide good shading effects, so make the living comfortable in burning hot summer.

\subsubsection{Dujiangyan irrigation project}

The Dujiangyan irrigation project, built more than 2260 years ago, helped Chengdu plain form a good gravity irrigation system. Plenty of rivers, ponds, ditches constitute a dense water network on the plain. This kind of terrain accords with the standards of site selection described in the Chinese ancient book GuanZi.: a place which is not at the foot of a high mountain, should be above a wide river, can be in highland but not near dry land, so the water is enough, in low places but not near water, then people need not pay attention to impermeability. Construction land is relatively homogeneous; families can get water nearby independently as there are many ditches around, so villages are dispersed into individual settlements. This kind of layout is quite different from the large centralized and street-style in the northern area in nature.

\subsubsection{The influence of immigration}

In the late Ming and early Qing dynasty, Sichuan suffered from wars; plummeting popularity accelerated the speed of population migration. From the 
mid-Shunzhi period in the Qing dynasty, the Qing government set the policy to recruit people for land reclamation. Thus formed a large-scale immigration destined for Sichuan. The number of each family is generally not too big, and then there are not so many families of the same clan or same race. Usually, there are at least one or two families of one clan or six to seven families at most. The families of one clan formed a Lin Pan. Therefore, each Lin Pan is not large scale.

\subsection{Settlement characteristics}

The forms of traditional Lin Pan do not share the same layout. The differences are tightly tied to topography, landform and drainage of settlements, and the final settlement form is closely related to these factors. Essentially, there are two ways to form the settlement.

\subsubsection{Linear structure}

The growth pattern of the LinPan along rivers and roads is linear. The villagers decided to live along rivers and roads to enjoy the convenience of transportation and irrigation. Then houses are joined into a single piece along the gallery as time passes. Thus the linear distribution of LinPan is the layout. This kind of LinPan generally exists in areas with plenty of water. Since the size of the settlement is enlarged step by step, and the paths of river systems are linear overall, so settlements built by people who live in accordance with the water formed a linear layout spontaneously.

\subsubsection{Radial growth}

Most of such LinPan expands in all directions with the central courtyard as the basic point, form courtyards like irregular polygons, such as triangle or trapezium, etc. Generally, this kind of Lin Pan locates in the comparatively remote areas of villages, does not have an obviously convenient outer environment, so it grows into a group structure.

\section{The utilization of land and the necessity of intensive utilization}

Through analysis of Lin Pan, the historical background of the formation of this kind of special settlement can be learned. It was formed under the conditions of small-scale peasant economy, occupied a larger homestead, and was suitable in ancient times when there was vast territory with sparse population. Because of the development of productivity, farming practice and industrial types changed a lot, and the population exploded, residential land became in great demand. A traditional settlement also faces the problem of a large occupation area and difficulty in management $[5,6]$. 


\subsection{Problems of the utilization of a traditional settlement}

\subsubsection{Problems of homestead}

Because in ancient times there were fewer people in one place, a traditional Lin Pan settlement usually took up too much area. Sometimes a four-person family homestead is more than $400 \mathrm{~m}^{2}$ and traditional rural settlements in Chengdu plain are generally dispersed, so there is a lot of room for agriculture between them. Therefore the settlement can be expanded without limitation. Actually, construction of housing is a significant reason why the agricultural land is reducing. In addition, when villagers move out or choose another homestead, the original homestead cannot be withdrawn in time and they are then left unused. These are all the problems that a traditional settlement is faced with.

\subsubsection{Developed construction technology makes better usage of vertical space}

Since the dwellings before only had one storey, when there is expansion, it must be a plain one, otherwise it would take up too much room. As the development of construction, there is no problem to building storied houses and making better use of vertical space. Therefore, more land can be vacated.

\subsection{The influence of intensive utilization of land upon settlement}

From the above questions, the necessity of the intensive use of land and its influence upon the traditional settlement should be noticed. The new rural construction is planned and designed according to these questions. But the newly-designed communities still have some negative problems.

\subsubsection{Changes of the layout of village}

In order to make intensive use of the land, peasants' houses have to be centralized in contrast to the former dispersed ones. The traditional settlement formed spontaneously, and there was no interference from government. While the government's guidance played an important role in the process of new rural construction, at present, the design in a new rural community always abandons the characteristics of traditional construction, and copies the arrangement mode in an urban residential district. This adoption completely changes the village style in west Sichuan. With the appearance of these centralized large-scale communities, the layout of villages is changed a lot from the original form. It has no relation to the former, lost the primary ecological and organic features and shows many signs of over urbanization.

\subsubsection{Changes of single building}

Construction forms in some new rural communities are all in the same key. They take no consideration of regional, aesthetical or contextual factors in architectural styles. And designers just work hard without making deeper communication with villagers, even employing many design methods of modern construction. This kind of modern building which is isolated from traditions has nothing special. And this abrupt variation makes it hard for the villagers to get used to; the building itself has no life either. 
Residences, besides living rooms we usually use now, also include other spaces out of agricultural necessity, such as yards, sties, patios or store rooms for farm tools. While, after the unification of multi-story building, those rooms are gone and this change has brought much inconvenience to villagers’ lives.

\subsubsection{Changes of village space}

Many interfacial transition zones in the village have disappeared because of the appearance of these communities. The eaves and bilevel design of traditional rural houses offer a public place along the alleys - most beautiful scenes in the village happen here. New rural houses after land consolidation are self-built or constructed in a systematic way. Even both of the two ways are under the guide of integrated planning, they form quite different styles. The difference mainly falls on the connection with villagers. The users' voices must be listened to in the planning process because whether villagers are satisfied is the very criterion to measure whether a construction is successful.

Lin Pan blends the life of human beings and nature, makes living harmonious. It suits the productive and living needs of the agricultural age in Chengdu plain. It attaches importance to saving resources, making use of nature and the layout of waters. This ecological thought and the layout which is full of the spirit of country life are worth reserving and employing. But how to resolve the contradiction between modern and tradition, under the condition that the settlement in the village is not destroyed, residences of villagers are centralized and promote the intensive utilization of land to a certain extent, and the living standard of villagers' space is improved? Some practical examples show that new rural planning and design has paid attention to this issue.

\section{Planning and design strategies based on intensive utilization and settlement protection}

\subsection{Planning strategies}

\subsubsection{Gather or scatter according to the condition of land}

Actually, this strategy inherited the traditional construction principle. Although the self-built rural houses built by previous farmers seem to be located arbitrarily, from their point of view, the result is on the contrary. They are not designed from the general layout as is done now. The whole settlement is indeed a dynamic growth progress. It is not accomplished in one action or finished at one time. Therefore, whether it should be get-together or scatter has something to do with topography, landform, river system, climate and geomancy. This design principle should be followed deservedly. Then, to promote the intensive utilization of land, build a livable and ecological living environment.

\subsubsection{Assemble appropriately}

This rule is trying to avoid forming large communities like in cities after villagers have assembled in great number. Because the villagers' work radius has a close relation with population density, if the density is excessive, there must be 
a larger area of land being taken up, and the distance between their residences and cultivated land is increased. Then it is rather inconvenient to do farming. So the assembly scale should be controlled.

\subsubsection{Keep the yard}

Practically, individual labor and meticulous farming are still the main working patterns in Chengdu plain. The yard, including some functional spaces such as drying cereal, storing tools and spaces of sty, etc. is worth keeping.

\subsubsection{The reflection of construction features}

In the designing of monomers, the digging of the traditional settlement form and spirit in Chengdu plain must be emphasized. The construction form does not come from nothing in the historical evolution of thousands of years. Its formation is indispensible from local climate, productive mode, and construction level. And each settlement is formed by gathered monomers. Its texture, layout and landscape influence the form of final settlement. If the monomer has no cooperation with tradition, a completely different and with no regard to residents' living habits construction form and space is forced exist; the style of the whole settlement and villagers' living level will be affected.

\subsection{Sample schemas}

The new rural design is offered by Sichuan Sanzhong Architectural Design Co., Ltd. By collecting planar forms of traditional settlements from aerial photographs, designers can master the planning form better. And they would not copy the design technique of urban community. These are all worth learning. The new rural planning of $\mathrm{Xi} \mathrm{Yu}$ village demonstrates that the designer endeavored to keep a traditional settlement style. Redesigned planning follows the original layout and texture of a traditional settlement in the resolution of the entire style, promoting the intensive utilization of land as well as retaining the settlement of Lin Pan, adopting modern technique in monomers, extracting elements of dwellings, reserving spaces in yard and improving the villagers' living standard greatly. It seems better than the former hard modern design of community.

\section{Conclusions}

Through the analysis on the change of settlement in Chengdu plain, it can be realized that promoting intensive utilization of land is the basic platform of protecting farming land and increasing land efficiency. Centralized communities after adjustment become the new residential form. Certainly, the development of productivity has brought variations to the village. However, the traditional settlement also contains some disadvantages left by the backward production mode. When regarding the construction capital and utilization of land, although the construction of a centralized community can not completely employ the original scattered layout, it should still adopt the outstanding design technique of a traditional settlement. The traditional Lin Pan layout relates closely to nature. 
Its personal scale, spatial identifiability, variable and interesting layout has conformed to the terrain make the settlement pleasant and full of life.

Therefore, how to maintain balance among improving the spatial standard of reconstructed rural houses, keeping the traditional settlement and promoting the intensive utilization of land needs the designer to undertake well-constructed site survey beforehand. On the one hand, the condition of the site, the traditional form and the residential space should be well understood, for fear that the design will be over exaggerated and incompatible with the integrated environment. On the other hand, in order to avoid subsequent serial utilization problems after reconstruction, communication between designers and villagers should be paid attention to. Only by taking users' experiences and benefits into consideration, a win-win situation between land adjustment and a new residential construction of villages can be achieved.

\section{Acknowledgement}

Supported by the National Natural Science Foundation of China (No.51278421).

\section{References}

[1] Duan Peng, Liu Tian-hou. LinPan [M].Chengdu: Sichuan Publishing House of Science and Technology, 2004. (In Chinese) 段鹏, 刘天厚. 林盘 [M], 成都: 四川科学技术出版社. 2004.11.

[2] Zhao Yuan-xin. Chengdu Plains Traditional Settlements Evolution and Update Research on Morphological Perspective [D]. Chengdu: Southwest Jiaotong University, 2011. (In Chinese) 赵元欣, 形态学视野 下成都平原传统聚落演进与更新研究[D].成都: 西南交通大学硕士论文 2011.

[3] Shu Bo. Research on the Agriculture Landscape of Chengdu Plain [M]. Chengdu: Southwest Jiaotong University Press. 2012. (In Chinese). 舒波, 成都平原的农业景观研究 [M]. 成都: 西南交通大学出版社, 2012.

[4] Wu Liang-yong. Integrated Architecture [M]. Beijing: Tsinghua University Press, 1990. (In Chinese) 吴良镛, 广义建筑学 [M]. 北京: 清华大学出版社, 1990.

[5] Zhao Rong-ming. Research on Problems and Solutions of the Farmland Settlement Planning on Chengdu Fringe Area [D]. Chengdu: Southwest Jiaotong University, 2006. (In Chinese) 赵荣明, 成都城市边缘区乡村聚落规划设计面临的问题与对策研究[D],成都: 西 南交通大学硕士论文, 2006.

[6] Wang Jun, Yu Li, Luo Ming, Zhai Gang. Review on Progress in Land Consolidation [J]. Zhengzhou: Areal Research and Development, 2003, 04. (In Chinese) 王军, 余莉, 罗明, 翟刚. 土地整理研究综述 [J], 郑州: 地域研 究与开发, 2003.4 . 